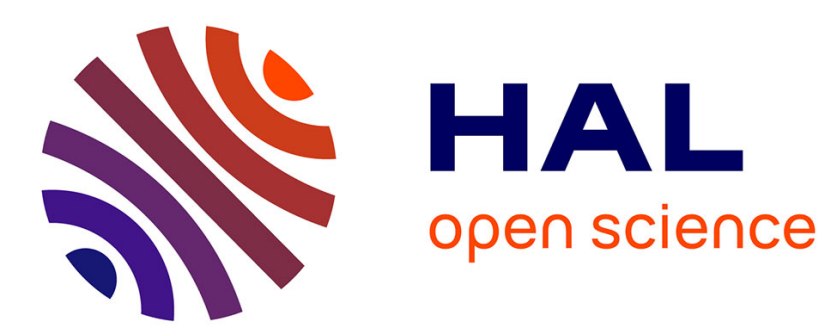

\title{
Joint effect of the western and eastern Pacific warm pools on ENSO cycle
}

\author{
Q. Qi, Y. Hou, Q. Zhang, T. Yan
}

\section{To cite this version:}

Q. Qi, Y. Hou, Q. Zhang, T. Yan. Joint effect of the western and eastern Pacific warm pools on ENSO cycle. Ocean Science Discussions, 2008, 5 (2), pp.163-185. hal-00298499

\section{HAL Id: hal-00298499 \\ https://hal.science/hal-00298499}

Submitted on 28 May 2008

HAL is a multi-disciplinary open access archive for the deposit and dissemination of scientific research documents, whether they are published or not. The documents may come from teaching and research institutions in France or abroad, or from public or private research centers.
L'archive ouverte pluridisciplinaire HAL, est destinée au dépôt et à la diffusion de documents scientifiques de niveau recherche, publiés ou non, émanant des établissements d'enseignement et de recherche français ou étrangers, des laboratoires publics ou privés. 
Ocean Sci. Discuss., 5, 163-185, 2008 www.ocean-sci-discuss.net/5/163/2008/ (C) Author(s) 2008. This work is licensed under a Creative Commons License.

\section{OSD}

5, 163-185, 2008

Joint effect of the western and eastern Pacific warm pools

Q. Qi et al.

\section{Joint effect of the western and eastern Pacific warm pools on ENSO cycle}

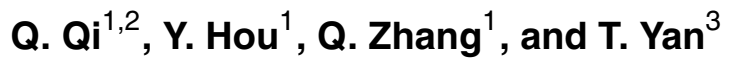

${ }^{1}$ Institute of Oceanology, Chinese Academy of Sciences, Qingdao 266071, China

${ }^{2}$ The Graduate School of the Chinese Academy of Sciences, Beijing 100039, China

${ }^{3}$ Climate Prediction Center, NOAA, Suitland MD 20746, USA

Received: 22 November 2007 - Accepted: 9 May 2008 - Published: 28 May 2008

Correspondence to: T. Yan (tingzhuang.yan @ noaa.gov)
Title Page

Abstract

Introduction

Conclusions

References

Tables

Figures

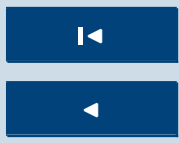

Back

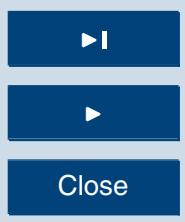

Full Screen / Esc

Printer-friendly Version

Interactive Discussion 


\section{Abstract}

The zonal displacement of the western Pacific warm pool (WPWP) and the meridional displacement of the eastern Pacific warm pool (EPWP) and their responses to wind anomalies over the tropical Pacific were investigated. Joint effect of the WPWP and 5 EPWP on ENSO was examined based on a joint effect index, which is a combination of the standardized anomaly time series of the eastern edge of the WPWP and the southern edge of the EPWP. Results show that both WPWP and EPWP are major providers of warm water in the eastern equatorial Pacific. The anomalous eastward extension of the WPWP and abnormal southward extension of the EPWP can supply 10 a large amount of warm water into Nino3 region of the north equator, result in dramatic local SST increase, and trigger EI Niño. To the contrary, as scope of the WPWP retreats westward and the EPWP retreats northward, a La Niña will outburst. One cannot separate apart the roles played by the WPWP and EPWP on ENSO, and the joint effect of both warm pools must be considered. A joint index of 1.6 means a new El 15 Niño event is likely to happen.

\section{Introduction}

It is well known that ENSO is one of the most important signals in interannual climate variations. Its occurrence is often associated with major global climate abnormity and serious drought or flood, and cold calamity in many regions of the world. Many countries undergo tremendous loss from industry and agriculture mal-practice, among them is China where serious droughts occur in the northern part, and heavy floods in the southern part. To understand the formation and evolution of the ENSO, meteorologists and oceanographers have carried out a wide range of studies during the past half century, and various theories were proposed, such as relaxation of trade wind (Wyrtiki, 1975), unstable ocean wave (Can and Zebiak, 1985; Hirst, 1986; Philander et al., 1984), the delayed oscillator (Battisti, 1988; Neelin, 1991; Suarez and Schopf, 1988),
OSD

$5,163-185,2008$

Joint effect of the western and eastern Pacific warm pools

Q. Qi et al.

\section{Title Page}

Abstract

\section{Full Screen / Esc}

Printer-friendly Version

Interactive Discussion 
and so on. Although each of these theories can explain partially the formation and evolution of ENSO, its principal causes and mechanisms remain unclear. Therefore, the predication of ENSO yet stays in experimental stage.

Previous classic views (Can and Zebiak, 1985; Long et al., 1990; Namias, 1976) 5 show that, El Niño is associated with the variation of trade wind over the tropical Pacific which is closely related to the oscillation of air pressure field, i.e., the South-Oscillation (SO). This coupled process makes up of so-called ENSO. The theory of trade wind relaxation indicates that the warm water builds up in the western Pacific if the trade wind is strong, resulting in sea level rising and thermocline deepening there; Once 10 the trade wind weakens, the warm water that piled up in the western Pacific collapse eastward in the form of Kelvin wave, causing anomalous warming in marine region near the South America. An El Niño would come into being. Obviously, this viewpoint emphasizes the effect of western Pacific warm water on the anomalous warming near the South America. Later, the impact of the western Pacific Warm Pool (WPWP) on 15 ENSO was intensively studied (Neelin, 1991; Philander et al., 1984; Shi, 2002; Suarez and Schopf, 1988; White et al., 1985).

It should be pointed out that although the WPWP expands eastward as far to the eastern coast of the Pacific Ocean during strong El Niño events (e.g. 1982, 1997), making whole equatorial Pacific covered by warm water $\left(T \geq 28^{\circ}\right)$, it does not extend eastward very far and its eastern edge is located most likely at west of $140^{\circ} \mathrm{W}$ (i.e., just entering Nino3 region) in most other El Niño years, such as 1951, 1963, 1965, 1969, 1976 and 1994 , especially 1951 and 1976 , the eastern edge was just at west of $150^{\circ} \mathrm{W}$ (i.e., beyond the Nino3 region) (Zhang and Weng., 1997), indicating that the anomalous warming in the eastern equatorial Pacific results partially from the eastward extension of WPWP and there may be other warm water providers. Recently, Zhang et al. (2004) analyzed the variation of the Eastern Pacific Warm pool (EPWP) and its relation to ENSO. They pointed out that the southward displacement of the EPWP plays an important role in triggering EI Niño. Therefore, it is believed that both WPWP and EPWP have important influence on ENSO cycle. Having been solely studied previously, two
OSD

$5,163-185,2008$

Joint effect of the western and eastern Pacific warm pools

Q. Qi et al.

Title Page

Abstract Introduction

Conclusions

Tables References Figures

14

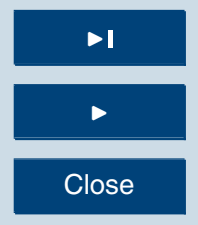

Back

Close

Printer-friendly Version

Interactive Discussion

EGU 
questions on the WPWP and EPWP remained unanswered. First, which warm pool is more important in affecting ENSO? Second, do they act jointly on the ENSO cycle? To clarify the above two questions, monthly average SST data $\left(2^{\circ} \times 2^{\circ}\right)(1950-2006)$ from the US National Climate Data Center and monthly average $850 \mathrm{hPa}$ wind data $5 \quad\left(2.5^{\circ} \times 2.5^{\circ}\right)(1949-2005)$ from the US National Centers for Environment Prediction are applied to investigate the variations of the WPWP and EPWP displacements and their joint effect on the ENSO cycle. In this paper, variations of the WPWP and EPWP displacements and their relation to ENSO cycle are analyzed, followed by analyses on the responses of WPWP's and EPWP's variability to wind anomalies, joint effect of 10 the WPWP and EPWP on the ENSO cycle is then discussed, and ended with some conclusions.

\section{Variability of the WPWP and EPWP displacements and ENSO cycle}

Previous studies indicated that distribution of the WPWP shifts seasonally with meridional displacement. Its main body occupies south of the equator in winter and then 15 moves northward in summer (Zhang et al., 2006). In addition, zonal displacement of the WPWP was so large that its eastern edge could reach the eastern Pacific, linking up with the EPWP in north of the equator during El Niño, and forming a long and narrow warm water zone. At the same time, the EPWP moves westward, reaching its westernmost location near $130^{\circ} \mathrm{W}$ and southward to its southernmost point near the

equator during El Niño. Obviously, if a study region was selected inappropriately, it would be difficult to determine the interface between the WPWP and EPWP, and hard to examine its variation and effect on ENSO. To accurately determine the boundary, the effect of the seasonal variation in the WPWP was eliminated by selecting the region covering eastern Pacific south of the equator $\left(5^{\circ} \mathrm{S} \sim 0^{\circ}, 130^{\circ} \mathrm{W} \sim 80^{\circ} \mathrm{W}\right)$ and the equatorial Pacific west of $130^{\circ} \mathrm{W}\left(5^{\circ} \mathrm{S} \sim 5^{\circ} \mathrm{N}, 120^{\circ} \mathrm{E} \sim 130^{\circ} \mathrm{W}\right)$ as the study region for WPWP, and the northeastern Pacific $\left(0^{\circ} \sim 24^{\circ} \mathrm{N}, 130^{\circ} \sim 80^{\circ} \mathrm{W}\right)$ was selected as the study region for the EPWP.

\section{OSD}

5, 163-185, 2008

Joint effect of the western and eastern Pacific warm pools

Q. Qi et al.

\section{Title Page}

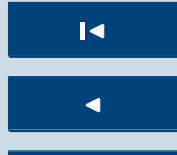

\section{Full Screen / Esc}

Printer-friendly Version

Interactive Discussion 
OSD

Based on average SST in each longitude degree of the study domain, monthly average position of the WPWP eastern edge (defined by $28^{\circ}$ isotherm) during 1950-2006 was derived. Statistical results show that the eastern edge can reached eastward 5 near $80^{\circ} \mathrm{W}$ (February-May, 1983; January-April, 1998) while westward close to $166^{\circ} \mathrm{E}$ (March, 1999). The annual average position is around $156^{\circ} \mathrm{W}$, which is 5 more longitudinal degrees eastward than Zhangs' (Zhang et al., 2004). The interannual variation of the WPWP eastern edge anomaly is very clear and corresponds well with the ENSO cycle (Fig. 1). Specifically, in early El Niño event, the anomaly would change from posi10 tive to negative with eastward moving; Once the event matures, the maximum anomaly would occur with the easternmost position. However, the distance of the eastward extension of WPWP is associated with the scale of El Niño. In strong El Niño (e.g. in 1997), the maximum eastward shifting could be 76 longitude degrees, while it could be only about 1.8 degrees in weak El Niño years (e.g. in 1951). On the other hand, 15 the distance of westward moving of WPWP is associated with La Niña scale. It moved westward for at least 27 longitude degrees in strong La Niña years (e.g. in 2000), while only 18 longitude degrees in weak La Niña years (e.g. in 1955). The prominent periods of the eastern edge series are 3.7-year, quasi-biennial oscillation (QBO) and 5-year mapped with power spectrum method (not shown). For convenience, the SSTA series in Nino3 region during 1950-2006 was also analyzed with power spectrum methodology. The results show that the major periods of the ENSO cycle are 3.7-year, 5-year and QBO, similar to those of WPWP. The correlation analysis also indicates a close relation between the displacement of the eastern edge and SSTA in Nino3 region with a correlation coefficient of 0.78 (>99\% confidence level), showing that the zonal vari25 ation of the WPWP affects largely on the formation of ENSO, which is consistent with previous studies (Fu et al., 1986; Long et al., 1990; Zhang et al., 2004).

In addition, the WPWP has obvious interdecadal variation in eastern edge anomaly. Generally, the anomalies are smaller before 1980s than later ones, indicating a sud-
5, 163-185, 2008

Joint effect of the western and eastern Pacific warm pools

Q. Qi et al.

\section{Title Page}

\section{Full Screen / Esc}

Printer-friendly Version

Interactive Discussion

EGU 
den climate change. Therefore, T-test in significance with 10-year-running mean (Ding and Jang, 1998) was conducted, and such climate change in 1981 was revealed (Tstatistic value is 3.99 , above the $99 \%$ confidence level). Before the climatic change (during 1950-1981), the eastern edge was located in average of -2.8 degrees more 5 western and 3.9 more eastern than those of 1982-2006 after the change, straddling 6.7 degrees. This significant shifting in the eastern edge of the WPWP since 1980s was probably the reason for frequent ENSO occurrences after the1980s.

\subsection{Variation of the EPWP south edge and the ENSO cycle}

The EPWP occupies the offshore area of the Central America east of the tropical Pacific

with large meridional movement of its southern edge whose southernmost location is around the equator (e.g. October 1982-June 1983; August 1997-May 1998) and the northernmost location around $14^{\circ} \mathrm{N}$ (e.g. January-February, 1955; January-February, 1975 ), in average of $8.9^{\circ} \mathrm{N}$. The interannual variation of the EPWP southern edge anomaly (Fig. 2) shows that the position changes interannually associated with ENSO cycle. In an early El Niño event, as the position moves southward, the anomaly turns from positive to negative. The position reaches its southernmost location with minimum anomaly once El Niño matures. During strong El Niño years (e.g. in 1982, 1997), however, the movement was the largest with maximum anomaly of -11.4 longitude degree; while in weak El Niño years (e.g. in 1951), the movement was smaller with anomaly of -1.7 degrees. In case of an La Niña, the southern edge shifts northward in early La Niña with anomaly sign from negative to positive, and reaches its northernmost position with maximum anomaly. Revealed in power spectrum, the major periods of the EPWP southern edge anomaly are 5-year, 3.7-year and QBO, similar to those of the ENSO cycle. A close correlation was identified between the southern edge and SSTA

in Nino3 region. ( $R=-0.73$ ), which is above $99 \%$ significance level.

In addition, the southern edge appears having experienced a sudden climate change in early 1980s (Fig. 2). The southern edge anomalies were relatively smaller before 1980 s than after 1980s. The 10-year running mean T-test analysis confirmed the cli-
OSD

5, 163-185, 2008

Joint effect of the western and eastern Pacific warm pools

Q. Qi et al.

\section{Title Page}

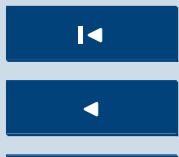
$\Delta$

\section{Full Screen / Esc}

Printer-friendly Version

Interactive Discussion EGU 
mate change (T-statistic (-4.29), exceeds the 99\% confidence level). Before 1980s, the southern edge was located northern in average anomaly of 0.7 longitude degrees; while after 1980s, it was -0.9 degrees. The difference was 1.6 degrees. Figure $3 a$ demonstrates the average extent of the WPWP and EPWP (boundary is defined by $528^{\circ}$ isotherm, thick black line) from 1950 to 2006, and Fig. 3b displays the typical extent of the two warm pools in May 1997 - onset of the 1997/98 El Niño (rectangle shows the Nino3 region).

The WPWP and EPWP are two warm-water engines driven for the eastern equatorial Pacific. In other words, they played important roles in the formation and development of 10 ENSO. Specifically, the WPWP and EPWP shift anomalously eastward and southward, respectively. As a result, a large amount of warm water flows into the eastern equatorial Pacific and warms up the seawater rapidly. For instance, from December 1982 to June 1983, the SSTs in Nino3 region were entirely above $28^{\circ} \mathrm{C}$, and even over $29^{\circ} \mathrm{C}$ in March-April 1983. Also, from May 1997 to May 1998 , all the SSTs exceeded $28^{\circ} \mathrm{C}$. On the other hand, when the eastward extension of the WPWP is weaker while the southward displacement of the EPWP is stronger, the eastern equatorial Pacific can also get relatively much warmer water and make local SST rise rapidly, and eventually triggers an El Niño event. However, the event is weaker because the warm water provided by the two warm pools is not enough, and the SSTs in the eastern Pacific increases slightly, for example the one in 1976. According to the Nino3 index, El Niño occurred in June 1976 and ended in January 1977. In the beginning of the event, the eastern edge of the WPWP was located at around $160^{\circ} \mathrm{W}$, which was 10 longitude degrees away from the western edge of Nino3 region. On the other hand, the southern edge of the EPWP reached southward $4^{\circ} \mathrm{N}$ and had entered the Nino3 region. However, during the event, the WPWP displaced eastward for a short distance and its eastern edge reached the farthest around $145^{\circ} \mathrm{W}$, meeting merely Nino3 region. At the same time, the EPWP stayed and did not extend southward. Therefore, Nino3 region had a smaller warming with a maximum SSTA of $0.95^{\circ} \mathrm{C}$. As the result, a weak event occurred in 1976. Other similar cases are not described in detail here.

OSD

5, 163-185, 2008

Joint effect of the western and eastern Pacific warm pools

Q. Qi et al.

\section{Title Page}

Abstract

\section{Full Screen / Esc}

Printer-friendly Version

Interactive Discussion 


\section{Response of the WPWP and EPWP displacements to wind anomalies}

As mentioned above, displacements of the WPWP and EPWP are strong enough to form and develop an ENSO. However, how do the warm pools respond to the wind anomalies over the tropical Pacific? This question is to be discussed below.

5 3.1 Response of the WPWP zonal displacement to zonal wind anomaly over the equatorial Pacific

The average standardized anomaly series of $850 \mathrm{hPa}$ zonal wind were calculated to analyze the response of the WPWP to zonal wind anomaly in the areas of western $\left(135^{\circ}-180^{\circ} \mathrm{E}, 5^{\circ} \mathrm{S}-5^{\circ} \mathrm{N}\right)$, central $\left(180^{\circ}-135^{\circ} \mathrm{W}, 5^{\circ} \mathrm{S}-5^{\circ} \mathrm{N}\right)$ and eastern $\left(135^{\circ}-80^{\circ} \mathrm{W}\right.$, $105^{\circ} \mathrm{S}-5^{\circ} \mathrm{N}$ ) equatorial Pacific, respectively.

The interannual variation in $850 \mathrm{hPa}$ zonal wind anomaly over the western equatorial Pacific (Fig. 4a) shows a good relationship to ENSO cycle. Namely, the westerly wind anomaly prevails over the western equatorial Pacific during EI Niño events while easterly wind anomaly prevails during La Niña events. A power spectrum analysis shows 15 that major periods of the zonal wind anomaly are QBO and 3.7-year, which is similar to those of the WPWP zonal displacement (3.7-year and QBO). Comparing Fig. 1 with Fig. 2, one can see that the eastward extension of the WPWP corresponds to the westerly wind anomaly and the westward recession to the easterly wind anomaly. However, there is a 4-month leading of the zonal wind anomalies before the zonal displacement at the best fit with a correlation coefficient of 0.56 at $99 \%$ significance level, indicating that the zonal displacement of the WPWP has a time lag behind about 4 months of the zonal wind anomalies over the western equatorial Pacific.

The interannual variation of zonal wind anomaly (5-month running mean) over the central equatorial Pacific (Fig. 4b) also shows a remarkable association with ENSO cycle. Alternatively, the westerly anomalies prevail in most El Niño events except the weak easterly anomalies in 1951 and 1953 and the easterly anomalies in La Niña years. The major periods of the zonal wind anomaly are 3.7-year, QBO and 5-year,

OSD

$5,163-185,2008$

Joint effect of the western and eastern Pacific warm pools

Q. Qi et al.

Title Page

Abstract Introduction

Conclusions

Tables References

Figures

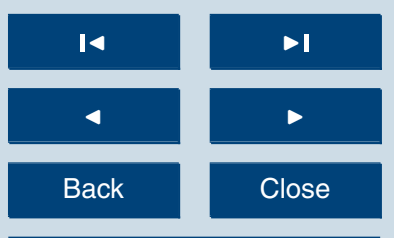

Full Screen / Esc

Printer-friendly Version

Interactive Discussion

EGU 
which is similar to the WPWP zonal displacement, indicating a good consistency between the WPWP zonal displacement and the zonal wind anomalies. By Comparing Fig. 1 and Fig. 4b, a time lag exists between the eastern edge and the zonal wind anomaly, and the best correlation is at 1-month leading of the zonal wind anomaly with 5 correlation coefficient of 0.76 at $99 \%$ significance. Obviously, there is a close relation between the zonal displacement and zonal wind anomaly over central Equatorial Pacific, and the former responses to the later with a lag of about 1 month.

The $850 \mathrm{~Pa}$ zonal wind anomaly over the central equatorial Pacific suggests a climatic transition (jump) at the end of 1970s. 10-year running mean T-test analysis 10 shows that the zonal wind anomaly had a climate jump near 1978 (the T-statistic value is 6.29 , above $99 \%$ confidence level). Before the climate jump (1949-1978), the average standard anomaly of the zonal wind is -0.43 , being the easterly wind anomaly, but 0.47 after the jump, being the westerly wind anomaly. Obviously, the climatic jump of the zonal wind anomaly over the central equatorial Pacific leads by around 3 years to that of the WPWP eastern edge.

The above statements suggest that the zonal displacement of the WPWP was mainly forced by zonal wind anomaly over the western and central equatorial Pacific. However, the impact of zonal wind anomaly over the western equatorial Pacific on the zonal displacement of the WPWP is different from that over the central equatorial Pacific. 20 The former triggers the WPWP displacement and the later drives to move the eastern edge of the WPWP until the wind direction is reversed.

3.2 Response of meridional displacement of the EPWP to meridional wind anomaly over the Northeastern Pacific

As stated above, the EPWP shifts clearly with meridional displacement. Does this 25

displacement respond to the meridional wind anomaly over the EPWP? To answer this question, the standardized anomalies of monthly $850 \mathrm{~Pa}$ meridional wind over the Northeastern Pacific $\left(0^{\circ} \sim 20^{\circ} \mathrm{N}, 90^{\circ} \sim 120^{\circ} \mathrm{W}\right)$ were calculated, and further smoothed by 11-month running mean for removing seasonal mean (Fig. 5). A clear climate transition
OSD

5, 163-185, 2008

Joint effect of the western and eastern Pacific warm pools

Q. Qi et al.

Title Page

Abstract Introduction

Conclusions

Tables References

Figures

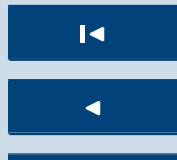

$\Delta$

Back

Close

Full Screen / Esc

Printer-friendly Version

Interactive Discussion

EGU 
in 1970s therefore was highlighted: the southerly wind anomalies prevail before the end of 1970s and the northerly wind anomalies prevail afterwards. 10-year running mean T-test analysis shows that the meridional wind anomaly experienced a climatic jump around 1978. The average standardized anomaly is -0.43 before the climatic

5 jump (1949-1978) and 0.47 after the sudden climate jump (1979-2005). Under such a background, the interannual variations of the meridional wind anomalies correlated weakly with ENSO cycles. Namely, before 1978, weak southerly wind anomalies were dominant in El Niño events and strong southerly anomalies in La Niña events, and after 1978, strong northerly anomalies prevailed in El Niño events and weak northerly 10 anomalies or southerly anomalies in La Niña events. The power spectrum analysis indicates that the major periods of the meridional wind anomaly are 3.7-year, QBO and 28.4-year. Obviously, the interannual periods of the meridional wind anomalies are consistent with those of the EPWP southern edge. A close relation with 1-2 month leading of meridional wind anomalies to the southern edge of the EPWP has been

15 revealed with the correlation coefficient of -0.44 at $99 \%$ significance level. However, the climate jump of the meridional wind anomalies occurred 3 years earlier before that of the EPWP southern edge.

Therefore, the meridional displacement of the EPWP was mainly related to the meridional wind anomalies over the northeastern Pacific.

\section{Joint effect of the WPWP and EPWP on ENSO cycle}

As stated earlier, both displacements of the WPWP and EPWP had impact on ENSO cycle in history. Their interannual variations are well related to Nino3 index with the correlation coefficients of 0.78 and -0.73 , respectively. A question is then raised: do the WPWP and EPWP jointly affect ENSO? If yes, how much?

25 The average position of the eastern edge of the WPWP is near $150^{\circ} \mathrm{W}$ in $15 \mathrm{EI}$ Niño events, just reaching the west edge of Nino3 region before El Niño event, and $130^{\circ} \mathrm{W}$ entering Nino3 region after the event. Similarly, the average position of the southern

OSD

5, 163-185, 2008

Joint effect of the western and eastern Pacific warm pools

Q. Qi et al.

Title Page

Abstract Introduction

Conclusions

Tables

References

Figures

14

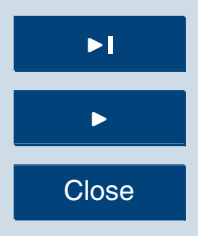

Back

Close

Full Screen / Esc

Printer-friendly Version

Interactive Discussion

EGU 
edge of the EPWP is located at about $6^{\circ} \mathrm{N}$, having not reached Nino3 region before $\mathrm{El}$ Niño events and then reaches $4^{\circ} \mathrm{N}$, entering Nino3 region in the month after the event. Obviously, whether the two warm pools have invaded Nino3 region is a precondition for an El Niño event. In other words, the abnormal warming in the central and eastern 5 equatorial Pacific is mainly resulted from the eastward displacement of WPWP and the southward expanding of EPWP. Therefore, the joint effect of the WPWP and EPWP on ENSO cycle should be studied.

First of all, a joint index expressing the zonal displacement of the WPWP and the meridional displacement of the EPWP should be given beforehand. The eastern edge 10 series of the WPWP and southern edge series of the EPWP are then used to present the joint index. The two time series are standardized due to the differences in unit. Taking the standardized WPWP eastern edge anomaly and EPWP southern edge anomaly as independent variables and SSTA in Nino3 region as a dependent variable, these time series are analyzed using multiple regression methodology. Under the condition 15 of $F=5.0$, the optimal linear regression equation is as following:

$Y=-7.383846 \times 10^{-2}+0.562524 X_{1}-0.2272252 X_{2}$

where $X_{1}$ and $X_{2}$ are the eastern edge anomaly of the WPWP and the southern edge anomaly of the EPWP, respectively, and both initiated in January 1950.

Since a regression coefficient reflects the overall contribution of independent variable 20 to dependent variable, the contribution of the WPWP is about one time greater than that of the EPWP due to probably the larger displacement amplitude of the WPWP than that of the EPWP, the same to the real situation that the area of the EPWP can impact is limited within Nino3 region north of the equator and east of $130^{\circ} \mathrm{W}$.

Remove the constant and simplify the coefficients in Eq. (1), the joint index of both 25 the WPWP and EPWP is written as

$Y=X_{1}-0.5 X_{2}$

Calculation using Eq. (1) and Eq. (2) yielded a correlation coefficient of 1.0, indicating 173
OSD

5, 163-185, 2008

Joint effect of the western and eastern

Pacific warm pools

Q. Qi et al.

Title Page

Abstract

Introduction

Conclusions

Tables

References

Figures

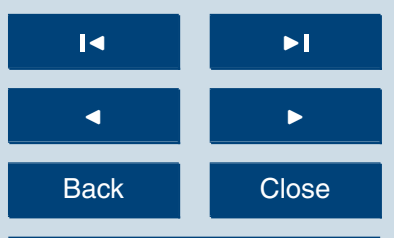

Full Screen / Esc

Printer-friendly Version

Interactive Discussion

EGU 
that the variation trends in the two time series are identical. In other words, Eq. (2) can be used to express the joint index of the WPWP and EPWP.

With Eq. (2), the interannual variation in the joint index is shown in Fig. 6. The joint index has a striking interannual variation associated well with ENSO cycle. Namely, 5 the joint indexes have large positive anomalies in EI Niño events, but large negative anomalies in La Niña events. In addition, the significant periods of the joint index are 3.7-year, 5-year and QBO, shown by power spectrum, and similar to those of ENSO. A strong correlation between the joint index and SSTA in Nino3 region was shown with the correlation coefficient of 0.86 higher than 0.78 between the eastern edge of the 10 WPWP and SSTA in Nino3 region and -0.73 between the southern edge of the EPWP and SSTA in Nino3 region. Obviously, the joint effect of these two warm pools on ENSO is much larger than that done singly. Our practice shows that the joint effect index is very useful for monitoring and forecasting ENSO.

Since both the eastern edge of the WPWP and the southern edge of the EPWP 15 underwent a climate jump around 1981, being processed with 10-year running mean T-test, the joint index showed also a climate jump in the same year (T-statistic value is -4.00 , exceeding the 0.001 confidence level) with the average value of -0.37 before the climatic jump (1950-1981) and 0.47 after the climatic jump (1982-2006) in difference of 0.84 .

20 To specify the variation of the joint index during ENSO, a composite analysis for 15 El Niño events (1951, 1953, 1957, 1963, 1965, 1968, 1972, 1976, 1982, 1991, 1993, 1994, 1997 and 2002) and La Niña events (1954, 1956, 1964, 1967, 1970, $1973,1974,1984,1988,1995$ and 1998) was conducted. As the event that processed with composite analysis, hereinafter terms composite event, usually initiates at the beginning of a year and matures at end of the year, the El Niño (La Niña) year was set as $Y(0)$, and the years before and after the EI Niño (La Niña) year as $Y(-1)$ and $Y(+1)$, respectively.

Figure 7 shows the evolution of the joint index in a composite El Niño event. The joint index is negative in the year before an El Niño event and turns positive at the

OSD

$5,163-185,2008$

Joint effect of the western and eastern Pacific warm pools

Q. Qi et al.

Title Page

Abstract Introduction

Conclusions

Tables References Figures

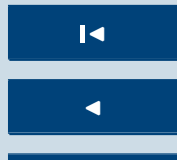
$\Delta$ 
beginning of El Niño year. Afterwards, it soars and reaches the maximum in August. Keeping changing for several months in form of wave, it sharply falls in the next April and becomes negative again after the next August, making the end of the El Niño event. On the contrary, the joint index is positive in the year before La Niña event and 5 becomes negative at the beginning of La Niña year, later it rapidly drops, reaches to the minimum in June, and stays for 4 months, then jumps after October and keeps negative value until the year after the event.

In addition, statistical results of those $15 \mathrm{El} \mathrm{Niño} \mathrm{events} \mathrm{show} \mathrm{that} \mathrm{the} \mathrm{average} \mathrm{joint}$ index in the month of an EI Niño onset is 1.2. However, affected by the climate jump, 10 the average joint index in $8 \mathrm{EI}$ Niño events before the climatic jump is 0.9 , while that in 7 El Niño events after the climatic jump is 1.6. Therefore, the joint index of 1.6 heralds the onset of a new El Niño event.

\section{Conclusions}

The zonal displacement of the WPWP and the meridional displacement of the EPWP 15 and their responses to wind anomalies over the tropical Pacific were studied, from which joint effect of the WPWP and EPWP on ENSO was discussed with the joint index introduced. The results are as follows.

The WPWP is a major provider of warm water in the eastern equatorial Pacific. As the anomalous eastward extension of the WPWP can supply a large amount of warm 20 water into the eastern equatorial Pacific, and result in local SST sudden increase, an EI Niño generates. On the contrary, warm water decrease and cold water increase when scope of the WPWP retreats anomalous westward from the eastern Equatorial Pacific, resulting in local SST sharp decrease and generation of a La Niña event.

The EPWP is also one of the warm water providers for the eastern equatorial Pacific. 25 Abnormal southward extension of the EPWP supplies warm water into Nino3 region north of the equator, which makes the SST rise and an EI Niño occurrence, whereas abnormal northward movement of the EPWP off the equator reduce warm water and

OSD

$5,163-185,2008$

\section{Joint effect of the western and eastern \\ Pacific warm pools \\ Q. Qi et al.}

Title Page

Abstract

Introduction

Conclusions

Tables References

Figures

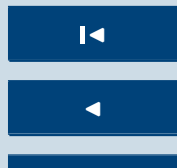

$\rightarrow$ I

Back

Close

Full Screen / Esc

Printer-friendly Version

Interactive Discussion

EGU 
increase cold water supply, resulting in anomalous SST cooling and then a La Niña outburst.

Zonal displacement of the WPWP is mainly induced by zonal wind anomalies over the western and central equatorial Pacific. When westerly wind anomaly prevails, the 5 warm pool extends eastward and vice versa. However, the impact of the zonal wind anomalies over the western equatorial Pacific would trigger zonal displacement of the WPWP, those over the central equatorial Pacific move the WPWP continually until the wind direction is reversed.

The meridional displacement of the EPWP is mainly caused by meridional wind 10 anomalies over the northeastern Pacific. The EPWP extends southward when northerly wind anomaly prevails or southerly wind anomaly withdraws and northward when southerly wind anomaly dominates there.

A joint effect index is defined based on the standardized anomaly time series of the eastern edge of the WPWP and the southern edge of the EPWP. The correlation 15 coefficient between the joint index and SSTA in Nino3 region is 0.85 , which is much higher than that between the eastern edge of the WPWP and the SSTA in Nino3 region and than that between the southern edge of the EPWP and SSTA in Nino3 region. Obviously, the joint effect of the two warm pools on ENSO is much larger than that of individual one. Therefore, we cannot separate apart the roles played by the WPWP

Acknowledgements. We are very grateful to the National Climate Data Center and Nation Centers for Environmental Prediction of the United States for data access. The project is supported by Chinese National Key Research Development Program (2006CB403606), National Key Foundation (90411013), and the Open Research foundation, National Key Laboratory of 25 the Satellite Marine Environment (200601).
OSD

$5,163-185,2008$

Joint effect of the western and eastern Pacific warm pools

Q. Qi et al.

\section{Title Page}

\section{Full Screen / Esc}

Printer-friendly Version

Interactive Discussion 


\section{References}

Battisti, D. S.: The dynamics and thermodynamics of a warm event in a coupled oceanatmosphere model, J. Atmos. Sci., 45, 2889-2919, 1988.

Bjeknes, J.: Atmospheric teleconnections from the equatorial Pacific, Mon. Weather Rev., 97, 163-172, 1969.

Can, M. A. and Zebiak, S. E.: A theory for El Niño and Southern Oscillation, Science, 228, 1085-1087, 1985.

Ding, Y. and Jang Z.: Processing for the signal of meteorological data series, Beijing, Meteorology Press, 46-47, 1998 (in Chinese).

$10 \mathrm{Fu}, \mathrm{C}$., Diaz, H. F., and Fletcher, J. O.: Characteristic of the response of sea surface temperature in the central Pacific associated with warm episodes of the Southern Oscillation, Mon. Weather Rev., 114, 1716-1738, 1986.

Hirst, A. C.: Unstable and damped equatorial modes in simple coupled ocean-atmosphere model, J. Atmos. Sci., 43, 606-630, 1986.

15 Huang, R. and Fu, Y.: Some study advancements and issues on the dynamics of ENSO cycle. The process and diagnose of the disaster climate, Beijing, Meteorology Press, 172-188, 1996 (in Chinese).

Long, B., Li, B., and Zou, E.: Anomalous eastward displacement of the western tropical Pacific warm pool and warming of the eastern tropical Pacific, Acta Oceanol. Sin., 20(2), 35-42, 1990.

Namias, J.: Some statistical and synoptic associated with El Niño, J. Phys. Oceanogr, 2, 130 138, 1976.

Neelin, J. D.: The slow sea surface temperature mode and the fast-wave limit: analytic theory for tropical interannual oscillations and experiments in a hybrid coupled model, J. Atmos. Sci., 48, 584-606, 1991.

Philander, S. G., Yamagata, T., and Pacanowski, R. C.: Unstable air-sea interactions in the tropics, J. Atmos. Sci., 41, 604-613, 1984.

Shi, N.: The multivariate analysis method in research and prediction on meteorology, Beijing, Meteorology Press, 34-40, 2002.

30 Suarez, M. J. and Schopf, P.: A delayed action oscillator for ENSO, J. Atmos. Sci., 45, 32833287, 1988.

White, B. B, Meyes, G. A., and Songuy, J. R.: Short-term climatic variability in the thermal
OSD

5, 163-185, 2008

Joint effect of the western and eastern Pacific warm pools

Q. Qi et al.

\section{Title Page}

Abstract

\section{Full Screen / Esc}

Printer-friendly Version

Interactive Discussion

EGU 
structure of the Pacific Ocean during 1979-1982, J. Phys. Oceanogr, 15, 917-935, 1985. Wyrtiki, K.: El Niño?the dynamic response of equatorial Pacific Ocean to atmospheric forcing, J. Phys. Oceanogr., 5, 572-583, 1975.

Zhang, Q., Hou, Y., and Cheng, M.: Eastern Pacific warm pool, Adv. Water Sci., 17(5), 676684, 2006.

Zhang, Q. and Weng, X.: Analysis of some oceanographic characteristics of the tropical western Pacific warm pool, Studia Marina Sinica, 31-38, 1997.

Zhang, Q, Weng, X., and Hou, Y.: Zonal movement of surface warm water in the western Pacific warm pool, Acta Oceanol. Sin., 26(1) 33-39, 2004.

\section{OSD}

$5,163-185,2008$

\section{Q. Qi et al.}

Joint effect of the western and eastern

Pacific warm pools

\section{Title Page}

\section{Abstract}

Introduction

Conclusions

References

Tables

Figures

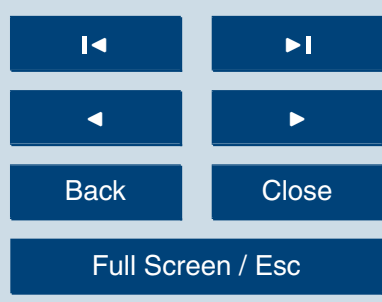

Printer-friendly Version

Interactive Discussion 
OSD

$5,163-185,2008$

\section{Joint effect of the} western and eastern

Pacific warm pools

Q. Qi et al.

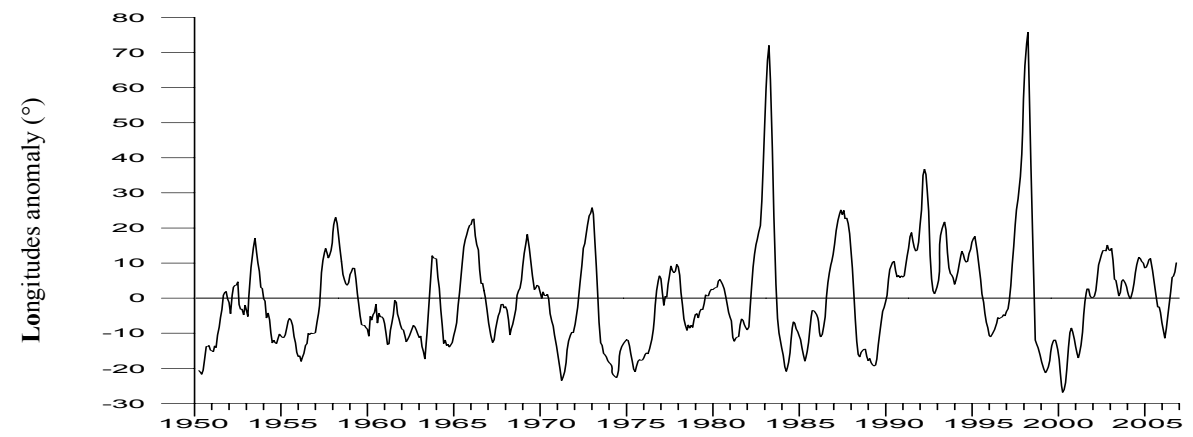

Fig. 1. Interanuual variation in the eastern edge anomaly of WPWP (5-month running mean). 
OSD

5, 163-185, 2008

\section{Joint effect of the} western and eastern

Pacific warm pools

Q. Qi et al.

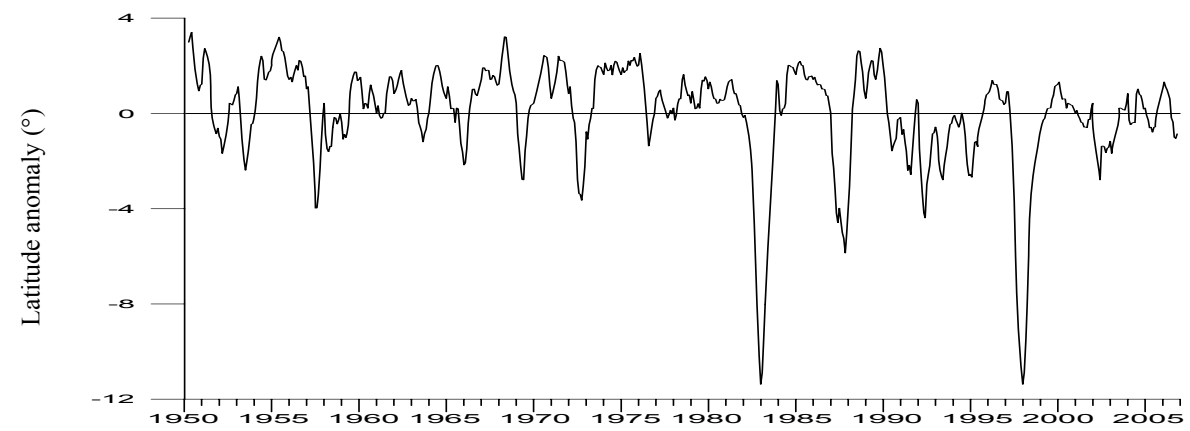

Fig. 2. Interannual variation of the southern edge of EPWP (5-month running mean). 
OSD

5, 163-185, 2008

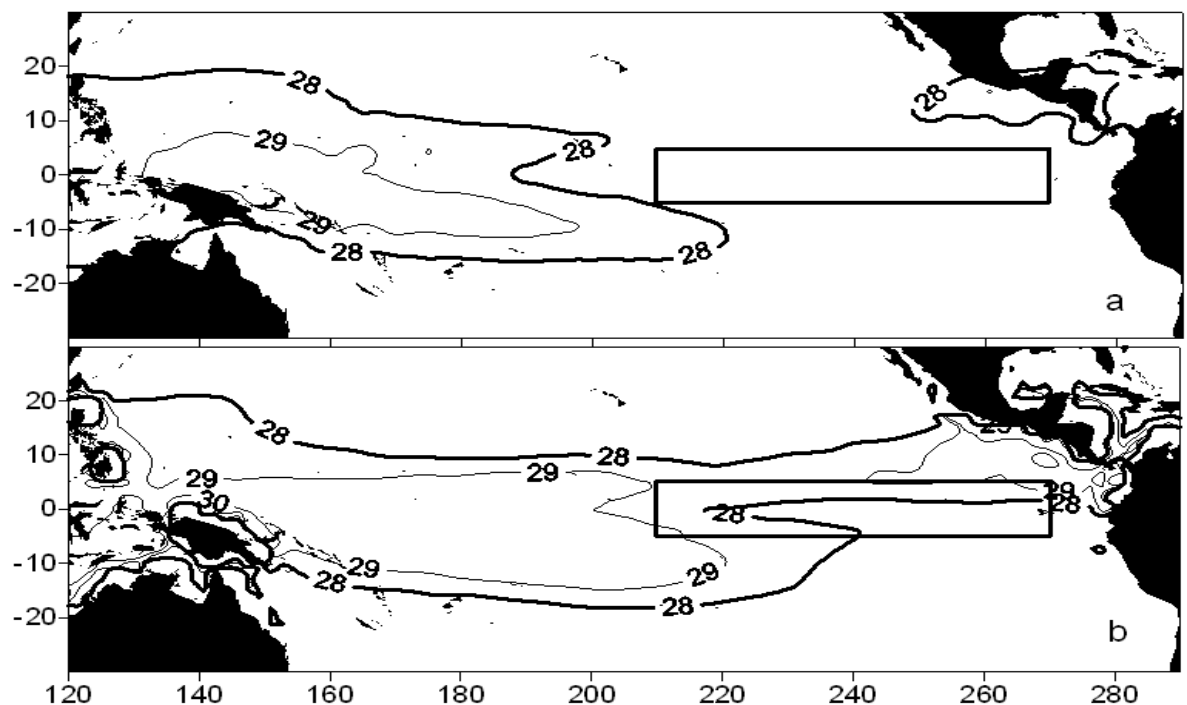

Joint effect of the western and eastern Pacific warm pools

Q. Qi et al.

\section{Title Page}

Abstract

Introduction

Conclusions

References

Tables

Figures
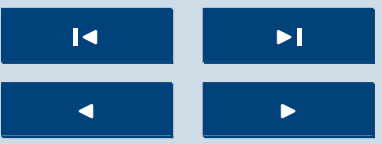

Back

Close

Full Screen / Esc

May 1997, which is onset of the 1997/98 El Niño (rectangle shows the nino3 region).

Printer-friendly Version

Interactive Discussion

EGU 


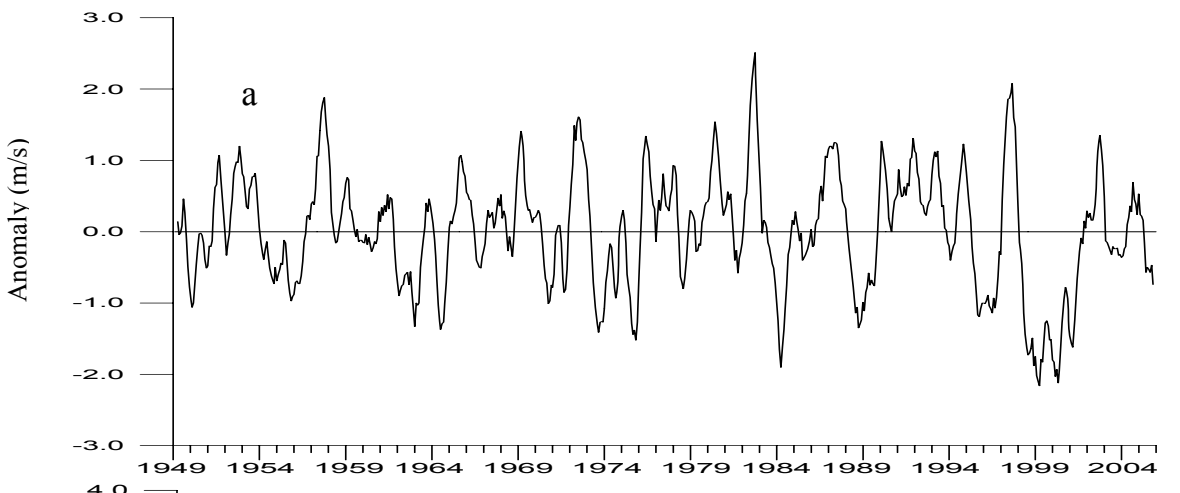

$5,163-185,2008$

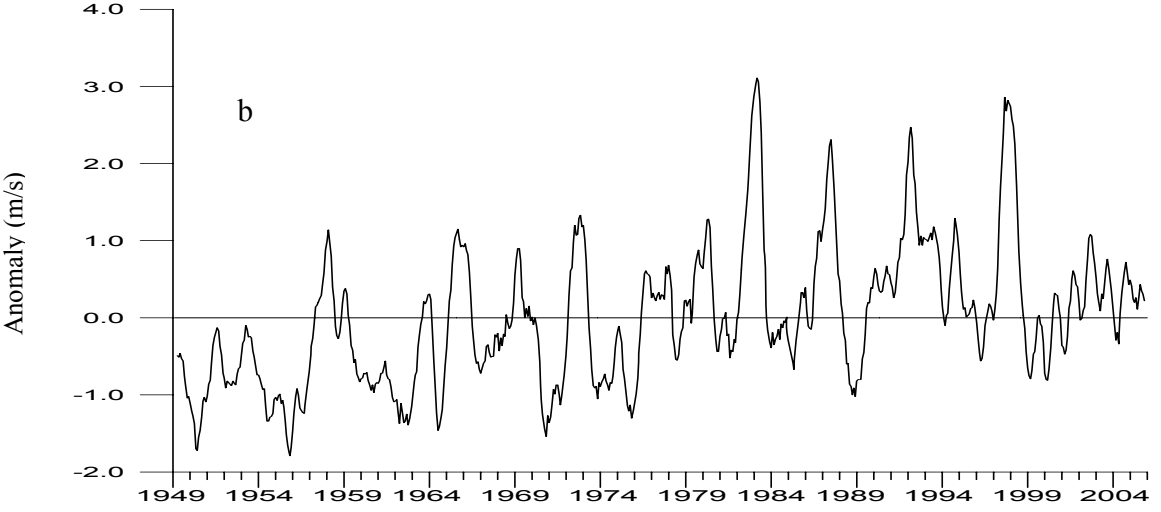

Joint effect of the western and eastern Pacific warm pools

Q. Qi et al.

Title Page

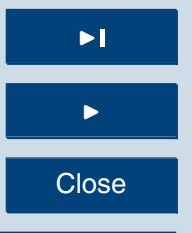

Fig. 4. Interannual variation in $850 \mathrm{~Pa}$ zonal wind anomaly over: (a) the western and (b) central equatorial Pacific (5-month running mean). 
OSD

$5,163-185,2008$

\section{Joint effect of the} western and eastern

Pacific warm pools

Q. Qi et al.

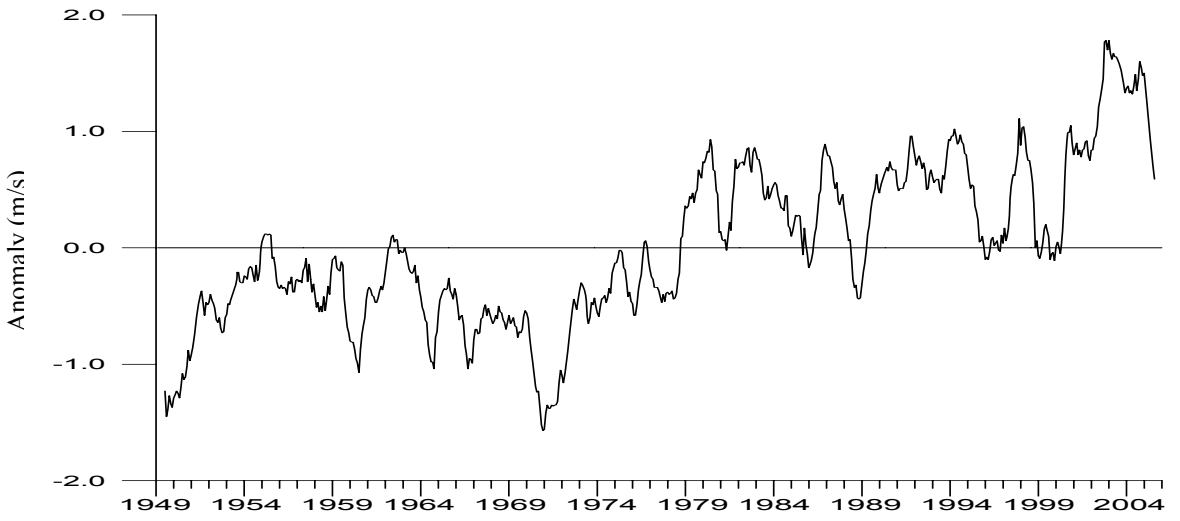

Fig. 5. Interannual variation of $850 \mathrm{~Pa}$ meridional wind anomaly over the northeastern Pacific (11-month running mean).

Title Page
Abstract

Conclusions

Tables

14

4

Back

Full Screen / Esc

Printer-friendly Version

Interactive Discussion 


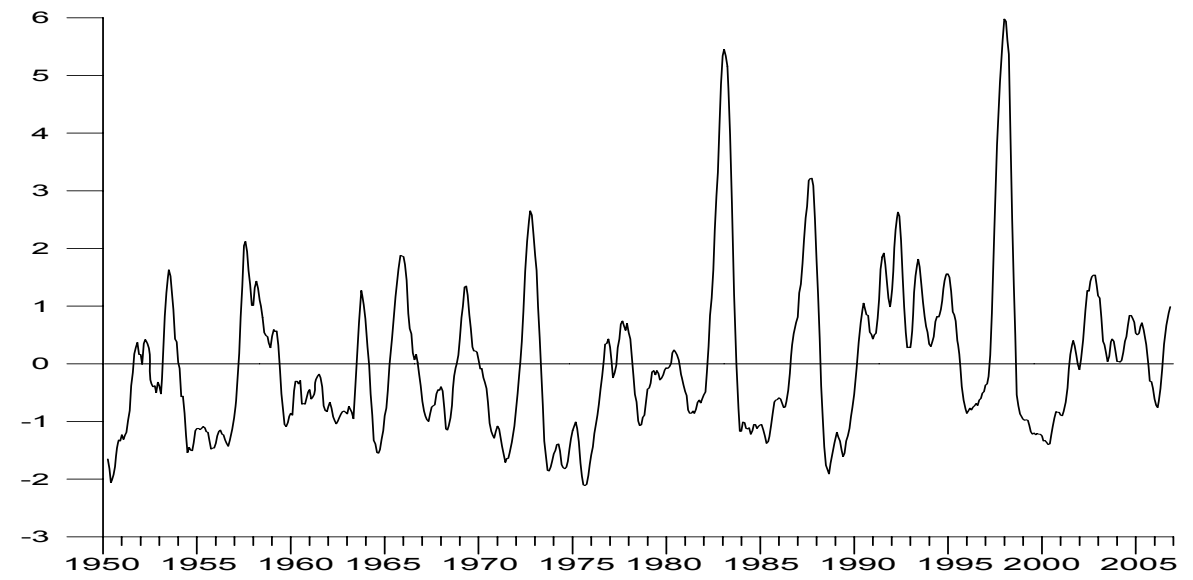

Fig. 6. Interanuual variation of the joint index of WPWP and EPWP (5-month running mean).
Joint effect of the western and eastern Pacific warm pools

Q. Qi et al.

Title Page

Abstract

Introduction

Conclusions

References

Tables

Figures

14

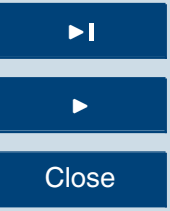

Back

Close

Full Screen / Esc

Printer-friendly Version

Interactive Discussion 
OSD

$5,163-185,2008$

Joint effect of the western and eastern

Pacific warm pools

Q. Qi et al.

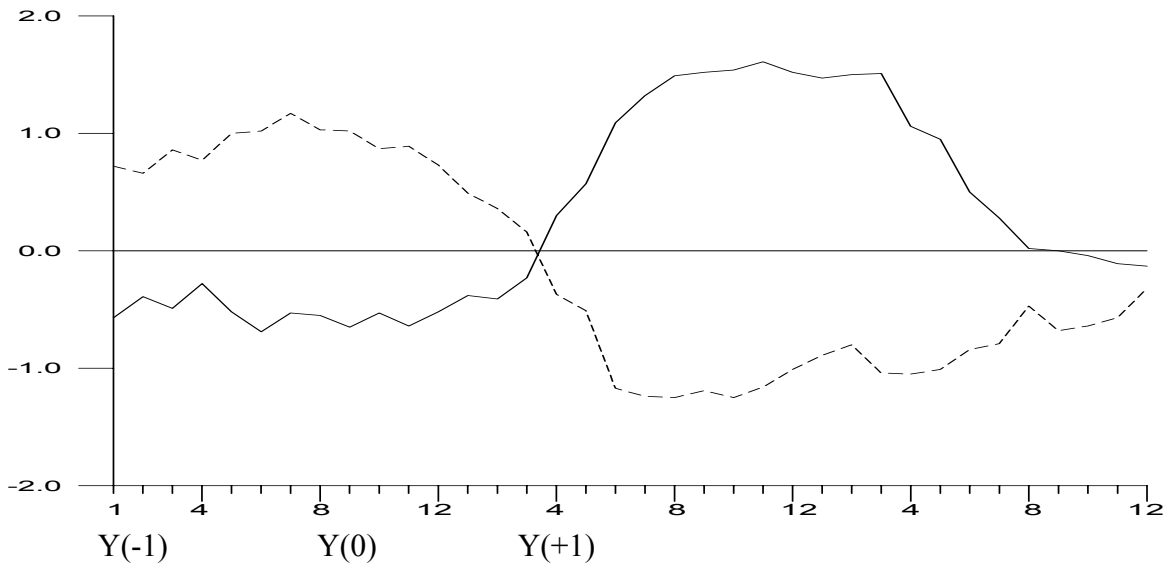

Fig. 7. The evolution of the joint index in composite El Niño (solid line) and La Niña (dotted line) events.
Title Page

Abstract

Introduction

Conclusions

References

Tables

Figures

14

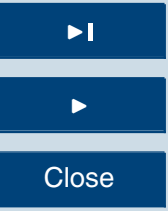

Back

Close

Full Screen / Esc

Printer-friendly Version

Interactive Discussion 